This is the pre-peer reviewed version of the following article:

"Parasitological and pathological findings in Fin Whales (Balaenoptera physalus) stranded along Italian coastlines" Diseases of Aquatic Organisms 133: 25-37, which has been published in final form at DOI: $\underline{10.3354 / \text { dao03327 }}$

This article may be used for non-commercial purposes in accordance with InterResearch Science Publisher Terms and Conditions for Use of Self-Archived Versions. 


\section{Parasitological and pathological findings in Fin Whales (Balaenoptera physalus) stranded along Italian coastlines}

\section{Parasitological findings in Mediterranean Fin Whales}

Marcer F..$^{*}$, Marchiori E. ${ }^{1}$, Centelleghe C. ${ }^{2}$, Ajzenberg D. ${ }^{3}$, Gustinelli A. ${ }^{4}$, Meroni V. ${ }^{5}$, Mazzariol S. ${ }^{2}$

${ }^{1}$ Department of Animal Medicine, Production and Health, University of Padova, 35020 Legnaro (PD), Italy

${ }^{2}$ Department of Comparative Biomedicine and Food Science, University of Padova, 35020 Legnaro (PD), Italy

${ }^{3}$ INSERM, Univ. Limoges, CHU Limoges, UMR_S 1094, Tropical Neuroepidemiology, Institute of Neuroepidemiology and Tropical Neurology, F-87000 Limoges, France

${ }^{4}$ Department of Veterinary Medical Sciences, University of Bologna, 40064 Ozzano Emilia (BO), Italy

${ }^{5}$ Department of Microbiology and Virology, IRCCS San Matteo Hospital Foundation and Department of Internal Medicine and Clinical Therapy, University of Pavia, Pavia (PV), Italy

*Corresponding author: Federica Marcer

Department of Animal Medicine, Production and Health, University of Padova, Viale dell’Università, 16 - 35020 Legnaro (PD), Italy

e-mail: federica.marcer@unipd.it 


\begin{abstract}
Mediterranean fin whale population faces many threats to its conservation, including both anthropic and natural issues. Few records on the parasitofauna of this species are present for this geographical area. The aim of this survey was to investigate presence and impact of parasitic diseases in Mediterranean fin whales (Balaenoptera physalus). Seven animals, stranded along Italian coastlines in the period 2006-2015, were submitted to necropsy and parasitological examination. One protozoan parasite, Toxoplasma gondii was detected in one fin whale and, for the first time in mysticetes, was successfully genotyped as a type II strain with 15 microsatellite markers.

One crustacean (Pennella spp.) and four helminth taxa (Crassicauda boopis, Ogmogaster antarcticus, Tetrabothrium ruudi and Bolbosoma sp.) were overall detected and morphologically identified. Cases of infestation by adult P. balaenopterae included variable parasitic burdens; impairment of immune system was suspected to be present in most severe cases, as already described for other cetacean species. Immature stages of Pennella sp. were also detected in two animals and are here described for the first time in cetaceans. Infection by $C$. boopis was observed or suspected in five cases. Parasitic thrombi, involving renal vessels and vena cava, fibrosis of renal parenchyma and renal impairment were observed in association to this parasite. Larval nematodes associated to arteriosclerosis of the mesenteric arteries were detected. To our knowledge, this is the first report of C. boopis inside the Mediterranean Sea and these findings should prompt further investigation to evaluate the prevalence of this severe infection in Mediterranean fin whales.
\end{abstract}

Keywords: Balaenoptera physalus, helminth parasites, crustacean parasites, Toxoplasma gondii, Genotyping, Mediterranean Sea 


\section{Introduction}

2 Fin whales Balaenoptera physalus (Linnaeus, 1758) are the most abundant mysticetes in the

3 Mediterranean Sea. Genetic studies confirmed the existence of a resident Mediterranean population

4 (Bérubé et al. 1998) listed as vulnerable by the International Union for Conservation of Nature

5 (IUCN) Red List, since it is progressively decreasing.

Major concerns for their conservation are attributable to anthropic activities, with ship strikes considered as the most relevant threats (Panigada \& Notarbartolo Di Sciara 2012). In addition, natural diseases are considered a problem for their conservation: two outbreaks of Dolphin Morbillivirus

9 have been described in the Pelagos Sanctuary involving fin whale specimens during the period 20112013 (Mazzariol et al. 2016). Epidemics of this viral disease should be also regarded as one of the major threats for this species. In some cases, in cetaceans, this viral infection is associated to opportunistic infection, such as those related to Toxoplasma gondii. Despite the fact that most of the toxoplasmosis infections are referred to toothed whales, with the protozoan being recognized as responsible for abortion, encephalitis and systemic lethal disease (Migaki et al. 1990, Di Guardo et al. 2010), 2 reports of $T$. gondii exist in baleen whales, in particular a young fin whale stranded in Italy (Mazzariol et al. 2012), and a seropositive humpback whale (Megaptera novaeangliae) stranded in England (Forman et al. 2009).

As for T. gondii, only few data on other parasites in Mediterranean fin whales are reported (Tamino 1953, Malatesta et al. 1998, Cicek et al. 2007, Giorda et al. 2017). The large copepod Pennella balaenopterae Koren and Danielssen, 1877 (Copepoda, Pennelliidae) has been described here since long time and its presence on whales' skin in the Pélagos Sanctuary is considered almost regular (Tamino 1953, Notarbartolo Di Sciara et al. 2003). Its presence is easily detectable even in live animals, since the posterior part of their body emerges from the host's skin and trails free in the water, while the head penetrates the skin and blubber until reaching the muscular fascia. In small odontocetes, the intensity of infection has been positively correlated to deficiency of immune system 
in striped dolphins (Vecchione \& Aznar 2014). Among endoparasites, the trematode Ogmogaster antarcticus Johnston, 1931 (Digenea, Notocotylidae) was described in a fin whale stranded on the north-eastern coast of Tyrrhenian Sea. As for nematodes, infection by Crassicauda sp. was recently reported in a specimen of $B$. physalus, associated with a severe nephropathy and severe mesenteric lesions (Giorda et al. 2017). Infection by the species Crassicauda boopis Baylis 1920 is known to cause serious illness in baleen whales, since the localization of adult worms in the vascular and renal district can lead to lethal outcomes. This species has been described in fin whales from the Atlantic and Pacific Ocean, but no reports in the Mediterranean are present in literature (Lambertsen 1986, 1992, Lempereur et al. 2017).

In order to give a throughout picture on the effect of the parasites in the conservation of this species in the Mediterranean Sea, the parasitic findings and associated pathological changes in fin whales stranded along the Italian coastline in a ten years' period (2006-2015) have been described in this paper.

\section{Material and Methods}

Between October 2006 and January 2015 seven carcasses of fin whales, stranded along the Italian coastlines (Tyrrenian and Ligurian Sea), were necropsied on the stranding sites following standard protocols (McLellan et al. 2004) by the Cetacean stranding Emergency Response Team (C.E.R.T.), established by the Ministry for Environment, Territory and Sea at Padova University, in collaboration with the local Units of Health Institutions.

Biometric data, carcass condition code, body condition score, age estimation and sex of the stranded animals are reported in Table 1.

\section{Parasitological and pathological analyses for metazoan parasites}

Following post-mortem examination, whenever it was possible, parasitological analyses were carried out on skin, blubber and respiratory, gastrointestinal, cardiovascular, and urogenital systems. In 
particular, portions of skin and blubber with embedded crustacean parasites were collected; the bronchial tree was longitudinally opened and pulmonary parenchyma was dissected and inspected for parasites. Vessels and liver ducts were dissected and examined for lesions and parasites; portion of the liver was sliced, washed and the sediment was examined under a stereomicroscope. Stomach chambers and portions of intestine (small and large intestine at least $10 \mathrm{~m}$ each) were separately sampled and the contents were filtered with 1.0 and $0.5 \mathrm{~mm}$ mesh sieves; the material was then observed by stereomicroscope. As previously described by Lambertsen (1992), intestinal mucosa and mesenteric arteries were examined to detect lesions due to the migration of parasitic larvae of the genus Crassicauda. Renal vessels and vena cava were also examined to search for adult specimens of Crassicauda boopis or related lesions. Ureteral ductworks were opened and accurately examined to isolate the tails of this nematode. When possible, urine sediment, obtained by centrifugation at $2000 \mathrm{rpm}$ for 5 minutes, was analyzed for the detection of eggs or larvae of Crassicauda. All parasites recovered during post mortem examination were washed in physiological saline, counted and fixed in $70 \%$ ethanol.

Morphometric characteristics of crustacean species of the genus Pennella were studied by stereomicroscopy. The nematodes and immature stages of crustaceans were examined as wet-mounts in clearing agents (glycerin or Amman's lactophenol), whereas flatworms were stained with Semichon's Acid Carmine and mounted in Canada balsam. All parasites were measured under light microscope (Nis Elements D software, Nikon).

Crustacean parasites were compared with descriptions by Thompson (1905), Hogans (1987) and Abaunza et al. (2001). Dichotomous keys and literature data were used to identify the helminths (Delyamure 1955, Margolis \& Pike 1955, Lambertsen 1985, Raga et al. 1986, Bray et al. 2008).

Specimens of $C$. boopis were deposited at the Natural History Museum of London (NHMUK) (accession number: Crassicauda boopis 2015.10.11.1-4).

Tissue samples showing lesions were fixed in $10 \%$ buffered neutral formalin, paraffin-embedded, cut (4 $\mu \mathrm{m}$ thickness) and routinely stained with hematoxylin and eosin for microscopic examination. 
Further histochemical techniques were used on selected sections in order to gain better information on pathogens and tissue changes (PAS and Masson's Trichromic).

\section{Analyses for protozoan parasites}

During necropsy, tissue samples (brain, spinal cord, heart, lymph nodes, skeletal muscle, lung, spleen, liver and kidney) were collected; a portion of each tissue was processed for routine histological examination and an aliquot was stored at $-20^{\circ} \mathrm{C}$ and subsequently analyzed by molecular methods to detect parasites of the family Apicomplexa.

\section{DNA extraction and PCR assay for detection of Toxoplasma gondii, Neospora, and Sarcocystis}

DNA extraction was performed on all the aforementioned tissues using NucleoSpin ${ }^{\circledR}$ Tissue kit (Macherey-Nagel, Germany). The PCR reaction was carried out in $30 \mu$ volume containing 1 X PCR buffer, $2 \mathrm{mM} \mathrm{MgCl} 2,200 \mu \mathrm{M}$ each of the dNTPs, 2 U Platinum ${ }^{\circledR}$ Taq DNA Polymerase (Invitrogen, UK), $1 \mu \mathrm{M}$ of each primer, as described previously (Ho et al. 1996), and 1-3 $\mu$ l of DNA extract. This PCR assay permits to amplify a conserved region of the $n s s-r R N A$ gene (300 bp in size) of Neospora spp. and other Apicomplexa coccidian as Sarcocystis and Toxoplasma. The reaction mixture was first treated at $95^{\circ} \mathrm{C}$ for $5 \mathrm{~min}$, followed by 12 cycles at $94^{\circ} \mathrm{C}$ for $30 \mathrm{sec}$ and $58^{\circ} \mathrm{C}$ for $30 \mathrm{sec} ; 23$ cycles at $94^{\circ} \mathrm{C}$ for $30 \mathrm{sec}, 52^{\circ} \mathrm{C}$ for $30 \mathrm{sec}$ and $72^{\circ} \mathrm{C}$ for $30 \mathrm{sec}$ and a final extension step at $72^{\circ} \mathrm{C}$ for $7 \mathrm{~min}$. DNA extracted from $T$. gondii oocysts, isolated from a domestic cat, were used as positive control. PCR products were analysed by electrophoresis in SYBR Safe stained (Invitrogen, UK) 2\% agarose gel, visualised with Geldoc XR (Bio-Rad Laboratories, USA) under UV light, subsequently purified and sequenced at BMR-Genomics (Padova, Italy). The sequences were analysed using ChromasPro (version 1.42, Technelysium Pty Ltd., Australia) and compared in GenBank ${ }^{\mathrm{TM}}$ database using BLASTn program (http://www.ncbi.nlm.nih.gov/).

Extracted DNA was also tested by a commercial Real Time PCR assay (Toxoplasma Q- PCR Alert Kit, Nanogen Advanced Diagnostics S.p.a., Buttigliera Alta, Italy) on an ABIPRISM 7300 (Applied 
Biosystem Carlsbad, USA) following the manufacturer's instructions. The real-time PCR assay targeted the 529 bp repeat region (REP529, GenBank accession no. AF146527) of T. gondii DNA (Homan et al. 2000). All DNA samples were tested in triplicate and each assay was considered positive if at least one test of the triplicate was positive. Each PCR run included a negative control without DNA and, to check the absence of PCR inhibitors, each sample was coamplified with an internal control consisting of beta-globin gene.

\section{Genotyping of T. gondii strains}

DNA samples extracted from tissues that tested positive for $T$. gondii DNA $\left(\mathrm{C}_{\mathrm{t}}\right.$ value $\left.<32\right)$ were submitted to a genotyping analysis using 15 microsatellite markers distributed on 10 of 14 chromosomes, as described previously (Ajzenberg et al. 2010). ,Briefly, for each primer pair, the forward one was 5'-end labeled with fluorescein to allow sizing of PCR products electrophoresed in an automatic sequencer. PCR was carried out in a $25-\mu \mathrm{L}$ reaction mixture consisting of $12.5 \mu \mathrm{L}$ of 2X QIAGEN Multiplex PCR Master Mix (Qiagen, France), 5 pmol of each primer and $5 \mu \mathrm{L}$ of DNA. Cycling conditions were $15 \mathrm{~min}$ at $95^{\circ} \mathrm{C} ; 30 \mathrm{~s}$ at $94^{\circ} \mathrm{C}, 3 \mathrm{~min}$ at $61^{\circ} \mathrm{C}$, and $30 \mathrm{~s}$ at $72^{\circ} \mathrm{C}(35$ cycles $)$; and $30 \mathrm{~min}$ at $60^{\circ} \mathrm{C}$. One microliter of the PCR product was mixed with $0.5 \mu \mathrm{L}$ of a dye-labeled size standard (ROX 500, Applied Biosystems) and $23.5 \mu \mathrm{L}$ of deionized formamide (Applied Biosystems). This mixture was denatured at $95^{\circ} \mathrm{C}$ for 5 minutes and then electrophoresed using an automatic sequencer (ABI PRISM 3130xl, Applied Biosystems). The sizes of the alleles in bp were estimated using GeneMapper analysis software (version 4.0, Applied Biosystems).

\section{Results}

\section{Metazoan parasites and histopathological findings}

Six out of seven fin whales were positive for one or more parasitic species. Overall, 1,164 parasites were collected, belonging to one crustacean and four helminth taxa (Table 2).

Adult females of the mesoparasitic copepod Pennella balaenopterae (Copepoda, Pennellidae) were detected in five whales. Mild infection was observed in four animals, in which the parasites were 
anchored mainly on the back and on the abdominal region. In one case, a severe infestation (>200 parasites), involving the entire body surface, was observed (whale \#3).

Immature specimens of parasitic copepods of the family Pennellidae Burmeister, 1835 (Fig. 1) were collected from two animals. The head of the parasites was strongly embedded into the skin and blubber without reaching the muscular fascia, while the trunk and the abdomen emerged from the body of the host. These specimens were small in size ( $\mathrm{n}=6$; mean length: $33.9 \mathrm{~mm})$, showed a distinct cephalothorax dorsoventrally flattened and flecked with black pigment. Beyond the border of the cephalothorax the hamate second antennae projected, while the first pair of antennae was delicate and setose. In the ventral side of the cephalothorax, a prominent rostrum was present and the sturdy maxillipeds were situated posteriorly; ventrally in the anterior third of the cephalothorax the cuticle folds forming an hourglass design with a pair of spines in the central part. At the end of the cephalothorax a pair of cuticular pointed structures were laterally present. The filiform thorax extended to a length ten times that of the cephalothorax; the four pairs of thoracic limbs appeared well developed with bristles in the last two segments; the first and second limbs bifurcated in two extremities. The abdomen was filiform; eighteen pairs of bulges or short unbranched lateral appendages (with different degrees of development in the specimens) were visible along the abdomen, which terminated with a deep notch. On either side of this was a small bisetose appendage. The morphometric data of the immature specimens of Pennella sp. Oken, 1815 are reported in Table 3.

Specimens of cestodes were collected from the small intestine of one adult whale. Morphometric characteristics of the parasite and the morphology of the scolex (presence of well visible ear-like appendages and well-developed median lobes on the apical organ) permitted to ascribe the specimens to the species Tetrabothrius ruudi Nybelin, 1928 (Eucestoda, Tetrabothriidae). One specimen of acanthocephalan Bolbosoma sp. Porta, 1908 (Acanthocephala, Polymorphidae) was detected from the small intestine of one fin whale. The digenean Ogmogaster antarcticus Johnston, 1931 (Trematoda, Notocotylidae) was found in the rectum of three fin whales. 
155 Crassicaudosis was suspected in five out of seven examined whales. Adult worms of the nematode Crassicauda boopis were found in four cases (Table 2). A total of ninety-five tails of $C$. boopis (range: 7-40 parasites/host) were found inside the ureters of the positive animals. In three cases both kidneys were parasitized, while in one case a unilateral infection was observed. The anterior part of the tails was found penetrating the wall of the urinary ductworks and extending into the renal parenchyma (Fig. 2F). Histopathological examinations of kidney revealed multifocal chronic nephritis with massive fibrosis, glomerular sclerosis and tubular atrophy in two animals (\#4 and \#5). In fin whale \#4, larvated ova were histologically observed within the kidney pelvis among epithelial cells, in lumen of arterial renal vessels and in adrenal glands. Additionally, larvated eggs of Crassicauda sp. were also found in urinary sediment in fin whale \#5.

Cephalic ends of $C$. boopis protruded free and flowing in the vena cava lumen of two animals (\#4 and \#5). Large pendulous masses (Fig 2B) and fragments of mineralized parasites were grossly observed within the lumen of arterial renal vessels of other two whales (\#2 and \#3 respectively). Adult nematodes, peduncolate, knobby and mineralized proliferations obstructed partially or totally blood passage into the vessels. Microscopic exams revealed the presence of parasitic elements also inside these proliferations, containing large numbers of ova, completely embedded by connective tissue layers, multifocally infiltrated by mild chronic inflammatory population (Fig 2D). Nematodes observed lying within the lumen of the renal and adrenal arteries (Fig. 2E) were also partially embedded by a mixed chronic inflammatory response with a massive eosinophils prominence and a severe fibroblastic invasion. These changes multifocally infiltrated also the arteries' walls along with severe edema and hyperemia.

In fin whale \#5 mesenteric arteries were characterized by a mural thickening with intimal hyperemia and hemorrhages, multifocal necrosis with cavitation and mineralized area (Fig 2C): these findings reduced vascular lumina. Microscopic examination confirmed a chronic mineralizing endo-arteritis with abundant and severe eosinophilic infiltration sometimes associated to parasitic larvae. Several nodules were grossly observed in the mucosal layer of the intestine of the same animal (\# 5) (n >90; 
diameter: 6-7mm), containing amorphous material, occasionally associated to the presence of a single nematode larvae (Fig. 2A). Gross examination revealed a massive and diffuse greenish discoloration of muscular tissues in this fin whale. Severe eosinophilic infiltration was microscopically observed in several lymph nodes.

Epicardial and endocardial granulomas were detected in fin whales \#1 and \#6 with PAS positive traslucid remains consistent with parasitic fragments digested by the inflammatory reactions, but no parasites were isolated.

Additionally, nematode larvae were found free inside the lumen of the intestine of the calf whale \#6; some of them carried hints of pre and post-cloacal papillae, indicating a preadult stage.

\section{Protozoan parasites}

One (fin whale \#3) of the seven examined animals was positive for $T$. gondii DNA that was detected in heart, skeletal muscle, mesenteric lymph node and kidney samples (Table 4); the sequences showed 100\% homology with T. gondii (GenBank ${ }^{\mathrm{TM}}$ accession no. AY 663792). The DNA sample that was genotyped was extracted from the muscle sample, successfully amplified at 3 microsatellite markers, and was identified as T. gondii Type II.

No lesions related to toxoplasmosis were observed in the histological sections of the examined animal tissues.

\section{Discussion}

Complete parasitological surveys on fin whales living in the Mediterranean Sea are still lacking due to the technical complexities encountered during necropsy, the large size of these animals and, sometimes, to the difficulty of reaching the stranding site. Moreover, the preservation status of the carcasses affects the analyses that can be carried out.

The presence on Mediterranean fin whales of ectoparasitic copepods Pennella sp. has been known for a long time (Anthony \& Calvet 1905). Pennella spp. are large mesoparasites infecting both teleost 
fishes and marine mammals. The high variability of morphological features of species and stages of parasite development have generated much debate amongst taxonomists (Kabata 1979). Although numerous species of Pennella have been described, P. balaenopterae is the only recorded copepod species that parasitizes marine mammals (Hogans 1987, Abaunza et al. 2001). The life cycle of $P$. balaenopterae is poorly understood and only the adult female and the first naupliar stage have been identified (Abaunza et al. 2001, Arroyo et al. 2002). Intensity of infection by Pennella balaenopterae is considered an indicator of health status in cetaceans and long-term, cumulative tendencies of $P$. balaenopterae infestation can be associated with challenged dolphin's immune system, debilitating viral infection and high levels of polychlorinated biphenyls (Vecchione \& Aznar 2014). Two cases of severe infestation by Pennella spp. were described in fin whales stranded alive along Italian and Turkish coastlines (Benvenuti et al. 1991, Ciçek et al. 2007). In our study, the degree of infestation was mild in most cases, and comparable to that reported by other authors in fin whales from Antarctic (Nishiwaki \& Hayashi 1950, Mizue \& Murata 1952) and Atlantic waters (Raga \& Sanpera 1986). In one animal, positive to Dolphin Morbillivirus and Toxoplasma gondii infection (Mazzariol et al. 2012), a severe infestation was already reported. An impairment of the immune system can be suspected in the animal included in this study, mainly due to the presence of the viral infection, thus the higher parasitic burden matches with assumptions in literature.

Other two whales, which have encountered DMV (Mazzariol et al. 2016), showed the presence of immature stages of crustacean parasites belonging to the family Pennellidae. The morphological features of these parasites appear similar to those of the youngest individual of Pennella filosa (Linnaeus, 1758) described by Thompson (1905) in fish. This is the only report in literature for immature stages of Pennella genus from definitive host. Molecular analyses could be useful to ascribe these specimens to the species $P$. balaenopterae. The finding of young individuals of Pennella sp. in these two sick young whales suggests that the animals had decreased their mobility shortly before death, allowing during this period the colonization by the parasites, as proposed by Aznar et al. (1994) in dolphins affected by a viral epizootic disease. 
Adult tapeworms of the families Tetrabothriidae and Diphyllobothriidae are described in cetaceans.

Life cycles of these species involve a zooplankton crustacean as first intermediate host and marine mammals as their definitive hosts (Raga et al. 2008). Only the genera Priapocephalus Nybelin, 1922 and Tetrabothrius (Eucestoda: Tetrabothriidae) have been described in mysticetes and members of the genus Tetrabothrius have been isolated from fin whales worldwide. Tetrabothrius affinis (Lönnberg 1891) (syn. Tetrabothrius wilsoni) is reported by Delyamure (1955) in Norway, South Africa, New Zealand and Antarctica (South Shetlands islands); the same author reported T. ruudi in West Norway, France and Russian Pacific coast and Antarctica, but this genus had never been reported before in the Mediterranean.

Acantocephalan of the genus Bolbosoma are intestinal parasites of cetaceans. Most of the species are typical of baleen whales, which get infected most probably by ingestion of the cystacanth larvae contained in an intermediate or paratenic host (Gazzonis \& Merella 2012). Euphasiids and copepods have been demonstrated to carry larvae of the genus Bolbosoma (Shimazu 1975, Tsimbalyuk 1980, Gregori et al. 2012). Five species are described in Balaenoptera spp., i.e. B. brevicolle (Malm, 1867), B. nipponicum Yamaguti, 1939, B. turbinella (Diesing, 1851), B. balaenae (Gmelin, 1790) and B. hamiltoni Baylis, 1929 (Delyamure 1955). The pathogenicity is linked to the anchorage of the proboscis to the intestinal wall, which is reported to cause ulceration and even perforation (Gibson et al. 1998). No gross lesions were observed in the intestine of this animal, probably due to the presence of a single specimen.

The genus Ogmogaster Jägerskiöld, 1891 include six species, that are identified by the number of 253 longitudinal ridges on the ventral surface, the presence or absence of spines on the tegument and body 254 size (Raga et al. 1986). Ogmogaster antarticus was reported in fin whales from the Spanish Atlantic coasts and from the Mediterranean basin (Raga et al. 1986, Malatesta et al. 1998). The species shows wide diffusion and low host specificity, being reported in both cetaceans and pinnipeds. 1986) and is considered endemic in the Atlantic population (Lambertsen 1992). Lambertsen widely 
described the diffusion and the mechanisms of this parasitic disease in Atlantic fin whales (1986, 1992). Though the number of analyzed animals is limited, our data prove for the first time that this parasitic disease exists among the Mediterranean population. The degree of severity of the infestation appears to be from moderate to severe in our survey, considering the lesions observed. The localization of the parasite inside the hosts confirm the descriptions in literature, with the female specimens getting to the lumen of the vena cava with the cephalic portion and the male's head trapped in the renal venous vessels. Hypothetically, the localization of the head inside the lumen of vessels allows the worms to feed on host's blood (Lambertsen 1986). Depressed packed red cell volume (PCV) in infected whales, potentially due to chronic consumption of blood by the worms, was reported by Lambertsen but due to the post mortem conditions we could not perform a complete blood count to confirm the anemic condition. The massive inflammatory reaction of the host's tissues to the parasite was broadly observed, causing severe lesions that appeared very similar to those described in literature (Lambertsen 1986). Wide thrombotic masses occupying the lumen of vessels and diffuse flogosis and fibrosis of renal parenchyma were observed in all infected animals, with varying degrees of severity. Multidigitate masses pending in renal veins are also reported by Lambertsen, as consequence of the host's attempt to capsulate the parasite. Such lesions are made up of fibrocellular tissue and they depart from the tunica media of the vessels. In chronic cases, a mineralized core can be observed right around the worm. Occlusion of the renal veins can occur as a consequence of the tissue reaction around parasite's body. The lesions observed in this survey completely overlap this description, showing different degrees of severity, that appeared greater in the animal with the higher parasitic burden $(n=40)$. Thrombotic processes found in the kidney of this animal probably had reduced renal blood flow leading to organ impairment. Severe impact of the infection on the host was demonstrated also by serum biochemistry. High concentration of creatinine $(6.95 \mathrm{mg} / \mathrm{dL})$, urea $(157.8$ $\mathrm{mg} / \mathrm{dl}$ ) and electrolytes (phosphate and potassium: $24.06 \mathrm{mg} / \mathrm{dL}$ and $29.5 \mathrm{mEq} / \mathrm{L}$, respectively) were found in serum of the unique samples animal (Mignone, personal communication), significantly higher than those reported in literature in infected whales (Lambertsen 1992), In this individual, 
eosinophils infiltration was also appreciated in several lymph nodes and muscular tissues and not only associated to parasites: these findings supports a possible increase in eosinophils blood count. Hypereosinophilia has been supposed to affect brain function in marine mammals (Di Guardo 2011) and this condition could have played a role in the stranding together with the renal function impairment suggested by blood chemistry. Other important parasitic lesions, that could have affected the health of this individual, were due to the contemporary presence of larval elements within intestinal and mesenteric arteries' walls along with a severe and chronic inflammatory reaction. Reasonably this finding could support the hypothesis of larval migration of $C$. boopis from intestine to renal vessels through the tonaca media of mesenteric arteries, as speculated by Lambertsen (1992) and similarly to what occurs for Crassicauda sp. in Cuvier's beaked whales (Diaz-Delgado et al. 2016). Nevertheless, since the animal was previously affected by DMV determining a possible impairment of immune system, the association between larval migration and poor health condition cannot be clearly claimed.

In conclusion, crassicaudosis could represent a cause of concern for the Mediterranean population of fin whales. Particular attention should be paid to the probable wide diffusion of the parasite among the host population and to the high severity of the disease, inheriting further sampling effort.

Four types of Apicomplexa coccidians (Sarcocystiidae) are reported in cetaceans: Cystoisospora delphini in bottlenose dolphins, Sarcocystis spp. in toothed whales and in a striped dolphin, Neospora caninum in bottlenose dolphins, and T. gondii in four dolphin species, in one harbor porpoise (Phocoena phocena [Linnaeus, 1758]) and recently in one sperm whale (Physeter microcephalus Linnaeus, 1758) (Domingo et al. 1992, Di Guardo et al. 1995, Cabezon et al. 2004, Raga et al. 2008, Mazzariol et al. 2011). As for Mysticetes, the reports concerning Sarcocystiidae are limited; Akao (1970) described Sarcocystis balaenopteralis n. sp. in muscle tissues of a Sei Whale (Balaenoptera borealis Lesson, 1828) and Forman et al. (2009) reported the presence of $T$. gondii-specific antibodies in a Humpback whale (Megaptera novaeangliae, Borowsky, 1781) using the Sabin Feldman Dye 
Test. The presence of a coinfection by $T$. gondii and Dolphin morbillivirus was reported by Mazzariol et al. (2012), in one fin whale included in this study.

The result of genotyping indicates the presence of Type II. This genotype seems common in marine mammals since it was isolated in the California sea otter (Enhydra lutris [Linnaeus, 1758]), striped dolphin (Stenella coeruleoalba [Meyen, 1833]), bottlenose dolphin (Tursiops truncatus [Montagu, 1821]) and Walrus (Odobenus rosmarus [Linnaeus, 1758])(Cole et al. 2000, Miller et al. 2004, Sundar et al. 2008, Di Guardo et al. 2011); Non-type II genotypes were reported in marine mammals such as those belonging to haplogroup 12 in North America (formerly Type X and A) in the California sea otter (E. lutris) (Khan et al. 2011), harbor seal (Phoca vitulina Linnaeus, 1758) and Californian sea lion (Zalophus californianus [Lesson, 1828]), (Cole et al. 2000, Miller et al. 2004, Sundar et al. 2008, Van Bressem et al. 2009).

This study is the first genotyping attempt of a T. gondii strain from Mysticetes. Genotype II predominates not only in terrestrial mammals and birds of North America and Europe, but also in the marine environment of these areas.

It seems that the route of infection by $T$. gondii in cetaceans include ingestion of oocysts with contaminated water, as these animals feed mainly on cold-blooded animals as fish and invertebrates, which are not expected to support the tachyzoite and bradyzoite life-stages of $T$. gondii (Forman et al. 2009). The oocysts, under controlled laboratory conditions, can sporulate and remain viable in seawater for several months (Lindsay \& Dubey 2009) and they can remain infectious in filter-feeding fish's alimentary canals for some hours post-exposure (Massie et al. 2010). DNA of T. gondii was also detected in shellfish in USA, Brazil and in Italy (Putignani et al. 2011).

The infected fin whale was observed swimming in shallow water in front of the Tuscany coast some days before stranding and it could be supposed that the animal might have been infected in this period from coastal waters. The animal showed also a dolphin morbillivirus infection and high concentration levels of organochlorine pollutants in the tissues. These data confirm the opportunistic nature of 
Toxoplasma, which can infect immune-depressed animals, already threatened by infectious diseases and environmental contaminants (Mazzariol et al. 2012).

\section{Acknowledgments}

The authors thank Mrs. Eileen Harris, curator of the collections belonging to the Parasitic Worms group of the Parasites and Vectors at the Natural History Museum, UK; dr. Cinzia Tessarin (Department of Animal Medicine, Production and Health, University of Padova, Italy) for her support in molecular analyses; dr. Michele Povinelli and dr. Giuseppe Palmisano (technicians of the Department of Comparative Biomedicine and Food Science, University of Padova, Italy), for their valued help in the necropsy and sampling activities; dr. Martina Pagiaro to the contribution of parasitological analyses. The tissues used for this work have been kindly provided by the Mediterranean marine mammal tissue bank, located at the Department of Comparative Biomedicine and Food of the Padova University, Viale dell’Università 16, I-35020 Legnaro - Agripolis PD, Italy. This work was financially supported by a Research Project of Padova University (Prot. CPDA149521/14).

\section{Literature Cited}

Abaunza P, Arroyo NL, Preciado I (2001) A contribution to the knowledge of the morphometry and the anatomical characters of Pennella balaenopterae (Copepoda, Siphonostomatoida, Pennellidae), with special reference to the buccal complex. Crustaceana 74(2):193-210

Ajzenberg D, Collinet F, Mercier A, Vignoles P, Dardé ML (2010) Genotyping of Toxoplasma gondii isolates with 15 microsatellite markers in a single multiplex PCR assay. J Clin Microbiol $48(12): 4641-5$

Anthony R, Calvet J (1905) Recherches faites sur le cétacé capture a Cètte, le 6 octobre 1904 Balaenoptera physalus (Linné). Bulletin de la Soc Philomatique 
Akao S (1970) A new species of Sarcocystis parasitic in the whale Balaenoptera borealis. J Protozool 17:290-294

Arroyo NL, Abaunza P, Preciado I (2002) The first naupliar stage of Pennella balaenopterae Koren and Danielssen, 1877 (Copepoda: Siphonostomatoida, Pennellidae). Sarsia, 87:333-337

Aznar F, Balbuena JA, Raga JA (1994) Are epizoites biological indicators of a western Mediterranean striped dolphin die-off? Dis Aquat Org 18:159-163

Bérubé M, Aguilar A, Dendanto D, Larsen F, Notarbartolo Di Sciara G, Sears R, Sigurjonsson J, Urban-RJ, Palsbøll PJ (1998) Population genetic structure of North Atlantic, Mediterranean Sea and Sea of Cortez fin whales, Balaenoptera physalus (Linnaeus 1758): analysis of mitochondrial and nuclear loci. Mol Ecol 7:585-599

Benvenuti A, Bortolotto A, Gonnella S, Odierna A, Stanzani AL (1991) Report on rescue treatment of two whales in the Mediterranean. European Research on Cetaceans 5:118-123

Bray RA, Gibson DI, Jones A (2008) Keys to the Trematoda, Vol. 1, 2, 3. Natural History Museum, London, UK

Cabezòn O, Resendes AR, Domingo M, Raga JA, Agustí C, Alegre F, Mons JL, Dubey JP, Almería S (2004) Seroprevalence of Toxoplasma gondii antibodies in wild dolphins from the Spanish Mediterranean coast. J Parasitol 90(3):643-4

Cicek E, Oktener A, Capar OB (2007) First report of Pennella balaenopterae Koren and Danielssen, 1877 (Copepoda: Pennellidae) from Turkey. Turkiye Parazitol Derg 31(3):239-41

Cole RA, Lindsay DS, Howe DK, Roderick CL, Dubey JP, Thomas NJ, Baeten LA (2000) Biological and molecular characterizations of Toxoplasma gondii strains obtained from southern sea otters (Enhydra lutris nereis). 86(3):526-30.

Delyamure SL (1955) Helminthofauna of Marine Mammals (Ecology and Phylogeny). Edited by Skrjabin K. I., Academy of Sciences of the U.S.S.R. Laboratory of Helminthology, English translation, Jerusalem: Israel Program for Scientific Translation 
Díaz-Delgado J, Fernández A, Xuriach A, Sierra E, Bernaldo de Quirós Y, Mompeo B, Pérez L, Andrada M, Marigo J, Catão-Dias JL, Groch KR, Edwards JF, Arbelo M. (2016) Verminous Arteritis Due to Crassicauda sp. in Cuvier's Beaked Whales (Ziphius Cavirostris). Vet Pathol 53(6):12331240. Epub 2016 Apr 22

Di Guardo G, Corradi A, Agrimi U, Zizzo M, Morelli L, Perillo A, Kramer L, Cabassi E, Kennedy S (1995) Neuropathological lesions in cetaceans found stranded from 1991 to 1993 on the coasts of Italy. Eur J Vet Pathol 2(1):47-51

Di Guardo G, Proietto U, Di Francesco CE, Marsilio F, Zaccaroni A, Scaravelli D, Mignone W, Garibaldi F, Kennedy S, Forster F, Iulini B, Bozzetta E, Casalone C (2010) Cerebral toxoplasmosis in Striped Dolphins (Stenella coeruleoalba) stranded along the Ligurian Sea coast of Italy. Vet Pathol $47(2): 245-253$

Di Guardo G. (2011) Eosinophilia and domoic acid exposure: a pathogenetic hypothesis. Environ Res 111(8):1328-9

Di Guardo G, Di Cesare A, Otranto D, Casalone C, Iulini B, Mignone W, Tittarelli C, Meloni S, Castagna G, Forster F, Kennedy S, Traversa D (2011) Genotyping of Toxoplasma gondii isolates in meningo-encephalitis affected striped dolphins (Stenella coeruleoalba) from Italy. Vet Parasitol 183(1-2):31-36

Domingo M, Visa J, Pumarola M, Marco AJ, Ferrer L, Rabanal R, Kennedy S (1992) Pathologic and immunocytochemical studies of morbillivirus infection in striped dolphins (Stenella coeruleoalba). Vet Pathol 29:1-10

Forman D, West N, Francis J, Guy E (2009) The sero-prevalence of Toxoplasma gondii in British marine mammals. Mem Inst Oswaldo Cruz 104(2):296-8.

Gazzonis AL, Merella P (2012) Principali macroparassiti ed epiobionti dei cetacei: note biologiche. In: Cringoli G. (ed) Mappe parassitologiche 16, Cetacei dei mari italiani. Series Editor, Italy. 
409 Gibson DI, Harris EA, Bray RA, Jepson PD, Kuiken T, Baker JR, Simpson VR (1998) A survey of 410 the helminth parasites of cetaceans stranded on the coast of England and Wales during the period 411 1990-1994. J Zool 244:563-574

412 Giorda F, Ballardini M, Di Guardo G, Pintore MD, Grattarola C, Iulini B, Mignone W, Goria M, 413 Serracca L, Varello K, Dondo A, Acutis PL, Garibaldi F, Scaglione FE, Gustinelli A, Mazzariol S, 414 Di Francesco CE; Tittarelli C, Casalone C, Pautasso A (2017) Postmortem findings in cetaceans 415 found stranded in the Pelagos Sanctuary, Italy, 2007-14. J Wildl Dis 53(4):795- 803

416 Gregori M, Aznar FJ, Abollo E, Roura A, González AF, Pascual S (2012) Nyctiphanes couchii as 417 intermediate host for the acantocephalan Bolbosoma balaenae in temperate waters of the NE Atlantic. 418 Dis Aquat Org 99:37-47

419 Ho MSY, Barr BC, Marsh AE, Anderson ML, Rowe JD, Tarantal AF, Andrickx AG, Sverlow K, Dubey JP, Conrad PA (1996) Identification of Bovine Neospora Parasites by PCR Amplification and 421 Specific Small-Subunit rRNA Sequence Probe Hybridization. J Clin Microbiol 4(5):1203-1208 Hogans WE (1987) Morphological variation in Pennella balaenopterae and P. filosa (Copepoda: 423 Pennellidae) with a review of the genus Pennella Oken, 1816 parasitic on Cetacea. Bull Mar Sci $424 \quad 40: 442-453$

425 Homan WL, Vercammen M, De Braekeleer J, Verschueren H. (2000) Identification of a 200- to 300426 fold repetitive 529 bp DNA fragment in Toxoplasma gondii, and its use for diagnostic and quantitative $427 \quad$ PCR. Int J Parasitol 30(1):69-75

428 Kabata Z (1979) Parasitic copepoda of British fishes. Ray Soc Publs 152:1-468

429 Khan A, Miller N, Roos DS, Dubey JP, Ajzenberg D, Dardé ML, Ajioka JW, Rosenthal B, Sibley 430 LD. (2011) A monomorphic haplotype of chromosome Ia is associated with widespread success in 431 clonal and nonclonal populations of Toxoplasma gondii. mBio 2(6):e00228-11. doi:10.1128/mBio.00228-11. 
Lambertsen RH (1985) Taxonomy and distribution of Crassicauda species (Nematoda: Spirurida) infecting the kidney of the common fin whale (Balaenoptera physalus, Linnè, 1758). J Parasitol 7(4):485-488

Lambertsen RH (1986) Disease of common fin whale (Balaenopera physalus) crassicaudosis of the urinary system. J Mammals Res 67(2):356-366

Lambertsen RH (1992) Crassicaudosis: a parasitic disease threatening the health and population recovery of large baleen whales. Rev Sci Tech Off Int Epiz 11(4):1131-1141

Lempereur L., Delobelle M., Doom M., Healters J., Levy E., Losson B., Jauniaux T. (2017). Crassicauda boopis in a fin whale (Balaenoptera physalus) ship-struck in the eastern North Atlantic Ocean. Parasitol Open, 3: 1-6.

Lindsay DS, Dubey JP (2009) Long-term survival of Toxoplasma gondii sporulated oocysts in seawater. J Parasitol 95(4):1019-1020

Malatesta T, Frati R, Cerioni S, Agrimi U, DiGuardo G (1998) Ogmogaster antarcticus Johnston, 1931 (Digenea, Notocotylidae) in Balaenoptera physalus (L): first record in the Mediterranean Sea. Syst Parasitol 40,63-66

Margolis L, Pike GC (1955) Some helminth parasites of Canadian Pacific whales. J Fish Res Board Can 12:97-120

Massie GN, Ware MW, Villegas EN, Black MW (2010) Uptake and transmission of Toxoplasma gondii oocysts by migratory, filter-feeding fish. Vet Parasitol 169(3-4):296-303

Mazzariol S, Di Guardo G, Petrella A, Marsili L, Fossi MC, Leonzio C, Zizzo N, Vizzini S, Gaspari S, Pavan G, Podestà M, Garibaldi F, Ferrante M, Copat C, Traversa D, Marcer F, Airoldi S, Frantzis A, De Beraldo Quiros Y, Cozzi B, Fernandez A (2011) Sometimes Sperm Whales (Physeter macrocephalus) cannot find their way back to the high seas. A multidisciplinary study on a mass stranding. PLoS ONE 6(5):e19417 
Mazzariol S, Marcer F, Mignone W, Serracca L, Goria M, Marsili L, Di Guardo G, Casalone C (2012)

Dolphin Morbillivirus and Toxoplasma gondii coinfection in a Mediterranean fin whale (Balenoptera physalus). BMC Vet Res 8, 20

Mazzariol S, Centelleghe C, Beffagna G, Povinelli M, Terracciano G, Cocumelli C, Pintore A, Denurra D, Casalone C, Pautasso A, Di Francesco CE, Di Guardo G (2016) Mediterranean Fin Whales (Balaenoptera physalus) threatened by Dolphin MorbilliVirus. Emerg Infect Dis 22(2):3025

McLellan W, Rommel S, Moore M, Pabst D (2004) Right whale necropsy protocol. Final report to NOAA Fisheries for contract \#40AANF112525. 51pp.

Migaki G, Sawa TR, Dubey JP (1990) Fatal disseminated toxoplasmosis in a spinner dolphin (Stenella longirostris). Vet Pathol 27:463-464

Miller MA, Grigg ME, Kreuder C, James ER, Melli AC, Crosbie PR, Jessup DA, Boothroyd JC, Brownstein D, Conrad PA (2004) An unusual genotype of Toxoplasma gondii is common in California sea otters (Enhydra lutris nereis) and is a cause of mortality. Int J Parasitol 34(3):275-284 Mizue K, Murata T (1952) Biological investigations on the whales caught by the Japanese Antarctic whale fleet season 1949-50. Sci Rep Whales Res Inst 6:73-131

Nishiwaki M, Hayashi K (1950) Biological survey of fin and blue whales taken in the Antarctic season $1947-48$ by the Japanese fleet. Ibidem 3:132-190

Notarbartolo di Sciara G, Zanardelli M, Jahoda M, Panigada S, Airoldi S (2003) The fin Whale Balaenoptera physalus (L., 1758) in Mediterranean Sea. Mammal Rev 33(2):105-150

Panigada S, Notarbartolo di Sciara G (2012) Balaenoptera physalus (Mediterranean subpopulation). The IUCN red List of Threatened species 2012

Putignani L, Mancinelli L, Del Chierico F, Menichella D, Adlerstein D, Angelici MC, Marangi M, Berrilli F, Caffara M, Frangipane di Regalbono DA, Giangaspero A (2011) Investigation of Toxoplasma gondii presence in farmed shellfish by nested-PCR and real-time PCR fluorescent amplicon generation assay (FLAG). Exp Parasitol 127:409-417 
Raga JA, Sanpera C (1986). Ectoparasitos y epizoitos de Balaenoptera physalus (L., 1758) en aguas atlanticas ibericas. Inv Pesq 50(4):489-498

Raga JA, Anguilar A, Fernandez JP, Carbonell E (1986) Parasitofauna de Balaenoptera physalus (L., 1758) (Cetacea: Balaenoptereridae) en las costas atlanticas espanolas: I. Sobre la presencia de Ogmogaster antarcticus Johnston, 1931 (Trematoda: Notocotylidae). Rev Iber Parasitol 46:237-241 Raga JA, Aznar FJ, Balbuena JA, Fernández M (2008) Encyclopedia of Marine Mammals, Second Edition, ed. W. F. Perrin, B. Wursing, H G. M. Thewissen, 821-830. San Diego: Academic Press

Shimazu T (1975) Some cestode and acanthocephalan larvae from euphausiid crustaceans collected in the northern North Pacific Ocean. Bull Jpn Soc Sci Fish 41:813- 821

Sundar N, Cole RA, Thomas NJ, Majumdar D, Dubeu JP, Su C (2008) Genetic diversity among sea otter isolates of Toxoplasma gondii. Vet Parasitol 15:125-132

Tamino G (1953) Note sui cetacei. VIII. Rinvenimento di una giovane balenottera arenata sulla spiaggia dei Maronti (Isola d'Ischia), il 16 Novembre 1953. Atti della Società di Scienze Naturali e del Museo Civico di Storia Naturale di Milano, 92:123-126

Thompson MT (1905) Immature specimens of Penella filosa, Biol Bull 8(5):296-307

Tsimbalyuk EM (1980) Results of an examination of the parasite fauna of planktonic organisms in Far-Eastern seas of the USSR. Voprosy parazitologii vodnykh bespoz vo - noch nykh zhivotnykh. (Tematicheskii Sbornik). Aka - demiya Nauk Litovskoi SSR, Institut Zoologii i Parazitologii, Vilnyus $103-104$

Van Bressem MF, Raga JA, Di Guardo G, Jepson PD, Duignan PJ, Siebert U, Barrett T, Santos MC., Moreno IB, Siciliano S, Aguilar A, Van Waerebeek K (2009) Emerging infectious diseases in cetaceans worldwide and the possible role of the environmental stressors. Dis Aquat Organ 86(2):143-157

Vecchione A, Aznar FJ (2014) The mesoparasitic copepod Pennella balaenopterae and its significance as a visible indicator of health status in dolphins (Delphinidae): a review. J Mar Anim Ecol 7(1):4-11 


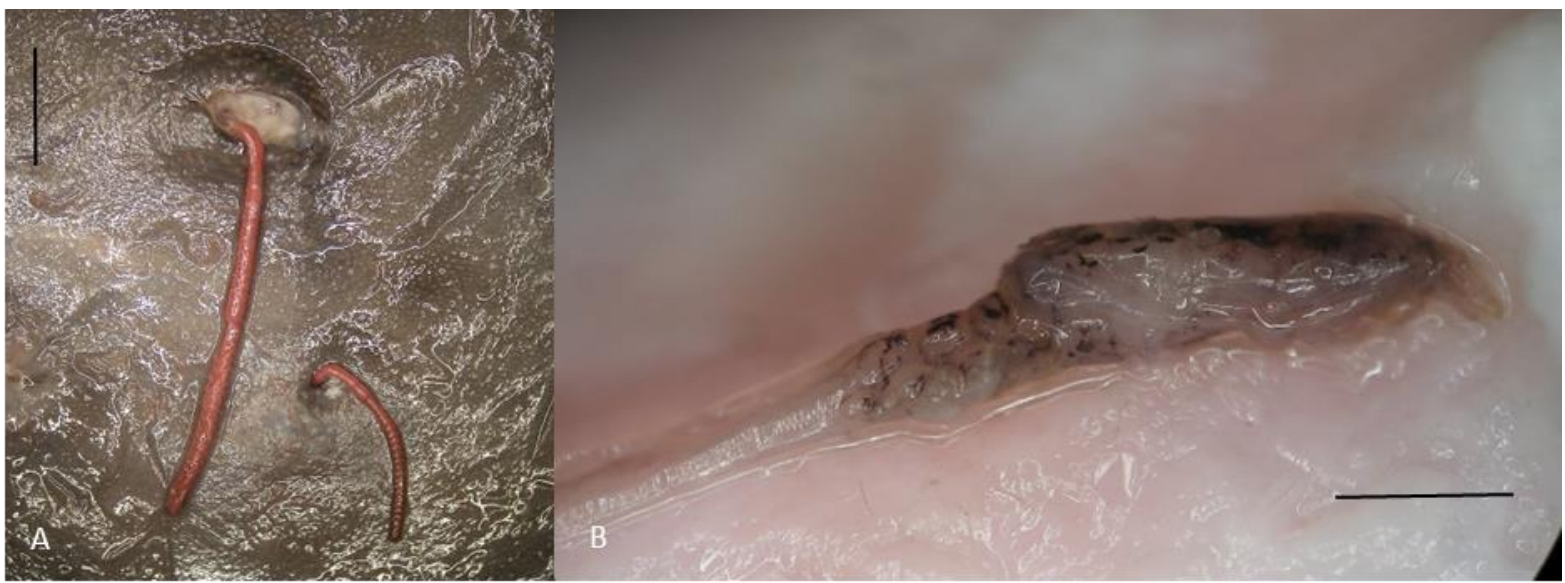

511 Fig.1: Immature stages of Pennella sp. (A). Abdominal portion of the parasite protruding from the 512 host's skin (bar=0.5 cm); (B) Lateral view of cephalothorax after removing the surrounding tissues 513 (bar=0.5 cm); (C) Ventral view of the head with first (black arrow) and second (black arrowhead) 514 antennae, rostrum (*) and maxillipeds (white arrow) (bar=300 $\mu \mathrm{m}$ ); (D) Cephalothorax, details of the 515 limbs (ventral view) $($ bar $=500 \mu \mathrm{m})$; (E) Abdomen of the parasite at two different developmental stages 516 of the appendages. 


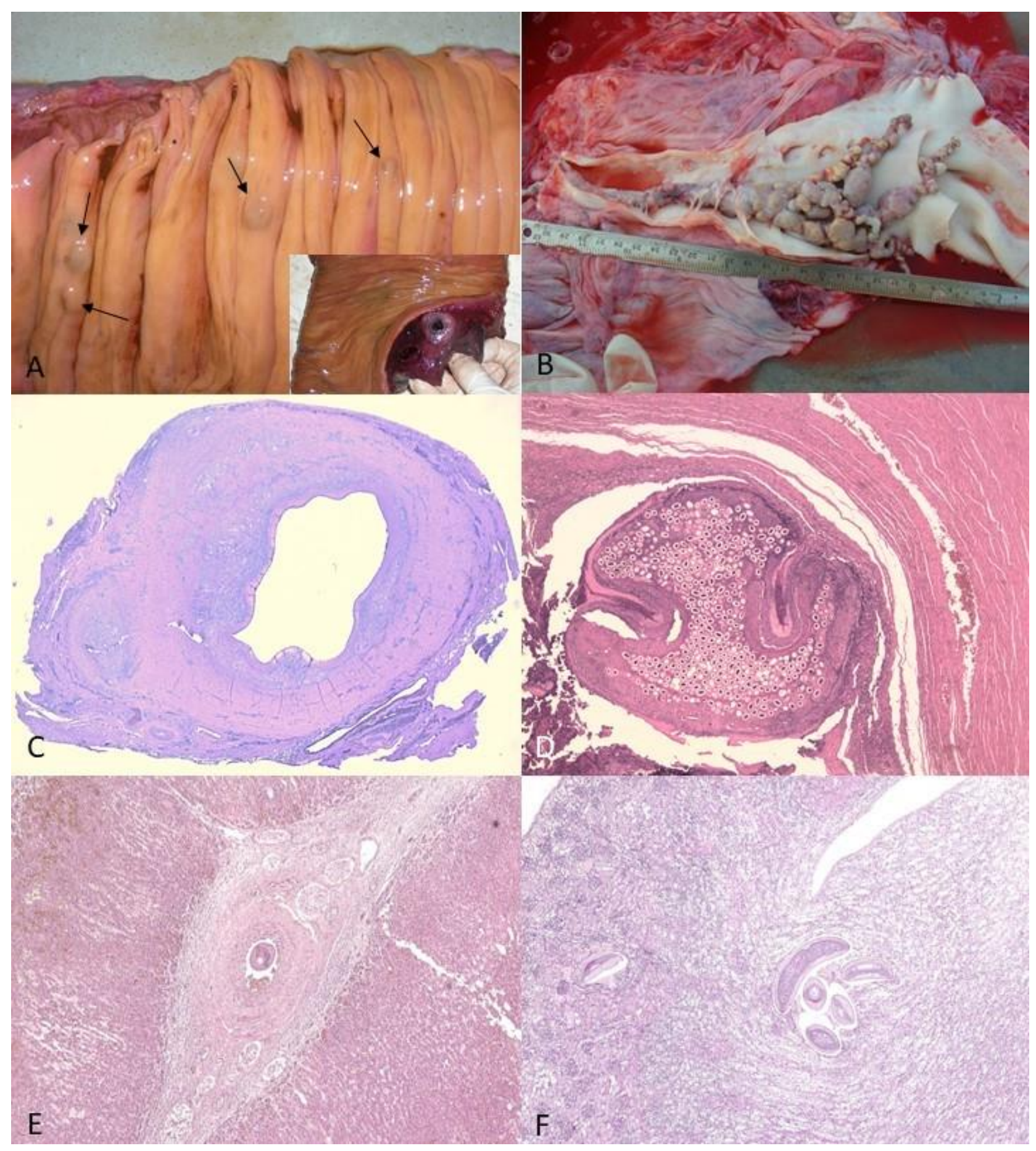

Fig.2: Nematode infections. (A) \#5. Multifocal, well-defined nodules (arrows), containing nematode

521 larvae (insert) visible on the surface of the intestinal mucosa. (B) \#2. Knobby and mineralized 522 formation in the vascular lumen of a renal vessel, partially obstructing blood passage. (C) \#5. 523 Histological section of a mesenteric artery characterized by a severe mural thickening with intimal 524 hyperemia and hemorrhages, multifocal necrosis with cavitation and mineralized area. 1X 525 magnification, Hematoxylin and Eosin (HE). (D) \#2. Parasitic thrombus formed by an adult element 
526 of $C$. boopis. 4X magnification, HE. (E) \#4. Adult element of $C$. boopis in the lumen of an artery in 527 the adrenal parenchyma, characterized by a severe fibroblastic invasion. 4X magnification, HE. (F) 528 \#6. Some adult elements of C. boopis in the renal parenchyma (medulla). 4X magnification, HE. 529 
Table 1. Data of fin whales specimens analyzed in this study

\begin{tabular}{|c|c|c|c|c|c|c|c|c|c|}
\hline Fin whale & ID & $\mathrm{CCC}$ & BCS & Age & Sex & Body lenght (m) & Year & Stranding site & DMV* \\
\hline$\# 1$ & 109 & 3 & Poor & Newborn & $\mathrm{M}$ & 5.57 & 2006 & Alassio (SV) & - \\
\hline$\# 2$ & 134 & 2 & Moderate & Juvenile & M & 13.40 & 2008 & Giannella (GR) & - \\
\hline$\# 3$ & 194 & 3 & Poor & Adult & $\mathrm{M}$ & 16.7 & 2011 & San Rossore (PI) & RT-PCR + (liver, spleen, lung) \\
\hline$\# 4$ & 208 & 2 & Poor & Juvenile & $\mathrm{F}$ & 10.78 & 2011 & Capo Testa (OT) & $\begin{array}{c}\mathrm{RT}-\mathrm{PCR}+\text { (liver, spleen, lymph } \\
\text { node, muscle) }\end{array}$ \\
\hline$\# 5$ & 211 & 2 & Poor & Juvenile & $\mathrm{M}$ & 10 & 2011 & Savona (SV) & $\mathrm{VN}+$ \\
\hline$\# 6$ & 297 & 2 & Poor & Newborn & $\mathrm{F}$ & 5 & 2013 & Marciana (LI) & $\begin{array}{l}\text { RT-PCR + (brain, spleen, lung, } \\
\text { thymus), IHC + (brain, thymus) }\end{array}$ \\
\hline$\# 7$ & 342 & 3 & Moderate & Adult & M & 17 & 2015 & Camaiore (LU) & - \\
\hline
\end{tabular}

ID = Identification code; $\mathrm{CCC}=$ Carcass Condition Code, according to Geraci and Lounsbury, 2005; BCS = Body Condition Score; F = Female; M = Male; DMV=Dolphin morbillivirus; RT-PCR = reverse transcription PCR; VN = virus neutralization; IHC = immunohistochemical analysis; * = Mazzariol et al. 2016 
Table 2. Metazoan parasites collected and identified from the examined fin whales.

\begin{tabular}{|c|c|c|c|c|c|c|c|c|}
\hline Organs & Parasite & Fin whale \#1 & Fin whale \#2 & Fin whale \#3 & Fin whale \#4 & Fin whale \#5 & Fin whale \#6 & Fin whale \#7 \\
\hline \multirow[t]{2}{*}{ Skin-blubber } & $\begin{array}{l}\text { Pennella balaenopterae } \\
\text { (Copepoda; Pennellidae) }\end{array}$ & Neg & 10 & 24 & 3 & 2 & Neg & 16 \\
\hline & $\begin{array}{l}\text { Immature stage of Pennella sp. } \\
\text { (Copepoda; Pennellidae) }\end{array}$ & Neg & Neg & Neg & 15 & Neg & 3 & Neg \\
\hline \multirow[t]{5}{*}{ Intestine } & $\begin{array}{l}\text { Ogmogaster antarcticus } \\
\text { (Trematoda; Notocotylidae) }\end{array}$ & $\mathrm{Neg}$ & 712 & 254 & $\mathrm{Neg}$ & $\mathrm{Neg}$ & Neg & 1 \\
\hline & $\begin{array}{c}\text { Tetrabothius ruudi. } \\
\text { (Eucestoda; Tetrabothriidae) }\end{array}$ & Neg & Neg & Neg & Neg & 8 & Neg & Neg \\
\hline & $\begin{array}{c}\text { Bolbosoma sp. } \\
\text { (Acanthocephala; Polymorphidae) }\end{array}$ & Neg & Neg & Neg & Neg & 1 & Neg & Neg \\
\hline & Nematoda larvae (inside nodules) & Neg & Neg & Neg & $\mathrm{Neg}$ & 7 & Neg & $\mathrm{Neg}$ \\
\hline & Nematoda larvae (free into the lumen) & Neg & Neg & Neg & Neg & Neg & 9 & Neg \\
\hline Kidney /ureters & Crassicauda boopis tails & $\mathrm{Neg}$ & $40(36 \mathrm{M} ; 4 \mathrm{~F})$ & Neg & $38(24 \mathrm{M} ; 14 \mathrm{~F})$ & $10(8 \mathrm{M} ; 2 \mathrm{~F})$ & Neg & 7 \\
\hline Vena cava & Crassicauda boopis heads & Neg & $\mathrm{Neg}$ & Neg & 11 & Pos & Neg & Neg \\
\hline $\begin{array}{l}\text { Mesenteric } \\
\text { arteries }\end{array}$ & $\begin{array}{l}\text { Nematoda larvae } \\
\text { (into the vessels wall) }\end{array}$ & $\mathrm{Neg}$ & $\mathrm{Neg}$ & $\mathrm{Neg}$ & $\mathrm{Neg}$ & 4 & $\mathrm{Neg}$ & Neg. \\
\hline
\end{tabular}


Table 3. Mean and individual measurements (in $\mu \mathrm{m}$ ) of six immature specimens of Pennella sp. Oken, 1815 in different developmental stages.

\begin{tabular}{|c|c|c|c|c|c|c|c|c|}
\hline Total length & & 33899 & 21582 & 26641 & 27245 & 32302 & 43525 & 52599 \\
\hline \multirow[t]{4}{*}{ Cephalothorax } & $\begin{array}{c}\text { Total length including } \\
\text { limbs }\end{array}$ & 2573 & 2404 & 2516 & 2420 & 2644 & 2694 & $2 \not 3 A 1$ \\
\hline & Head length & 1910 & 1726 & 1967 & 1847 & 1908 & 1978 & $\begin{array}{r}542 \\
2034\end{array}$ \\
\hline & Head width & 781 & 665 & 747 & 797 & 817 & 824 & 8543 \\
\hline & & & & & & & & 544 \\
\hline \multirow[t]{3}{*}{ Thoracic region } & $\begin{array}{l}\text { Diameter in the middle } \\
\text { region }\end{array}$ & 444 & 392 & 344 & 402 & 472 & 494 & 5595 \\
\hline & Total length & 25257 & 14655 & 18260 & 18475 & 23192 & 34271 & 426469 \\
\hline & & & & & & & & 547 \\
\hline \multirow[t]{4}{*}{ Abdomen } & Total length & 6068 & 4522 & 5865 & 6351 & 6467 & 6560 & 66458 \\
\hline & $\begin{array}{l}\text { Width in the middle } \\
\text { region }\end{array}$ & 364 & 340 & 365 & 370 & 310 & 324 & $\begin{array}{l}476 \\
549\end{array}$ \\
\hline & $\begin{array}{l}\text { Width including } \\
\text { appendages }\end{array}$ & 631 & & & & 630 & 668 & $59 \$ 0$ \\
\hline & Appendages & & $\begin{array}{c}\text { Poorly } \\
\text { developed }\end{array}$ & $\begin{array}{c}\text { Poorly } \\
\text { developed }\end{array}$ & $\begin{array}{c}\text { Poorly } \\
\text { developed }\end{array}$ & Present & Present & $\begin{array}{r}551 \\
\text { Present } \\
552\end{array}$ \\
\hline
\end{tabular}


555 Table 4. Results of T. gondii, Neospora, and Sarcocystis detection by PCR and sequencing.

\begin{tabular}{|c|c|c|c|c|c|c|c|}
\hline Tissues & Fin whale \#1 & Fin whale \#2 & Fin whale $\# 3^{\circ}$ & Fin whale \#4 & Fin whale \#5 & Fin whale \#6 & Fin whale \$56 \\
\hline Brain & Negative & Negative & NOT DONE & Negative & Negative & Negative & Negati \\
\hline Spinal cord & Negative & Negative & NOT DONE & Negative & NOT DONE & Negative & Negat \\
\hline Heart & NOT DONE & Negative & T. gondii $*$ & Negative & Negative & Negative & NOT DC \\
\hline Skeletal muscle & Negative & Negative & T. gondii $*$ & Negative & Negative & Negative & Negative \\
\hline Lymph nodes & Negative & NOT DONE & T. gondii $*$ & Negative & Negative & Negative & Negative \\
\hline Spleen & NOT DONE & NOT DONE & Negative & NOT DONE & NOT DONE & NOT DONE & NOT DON \\
\hline Liver & NOT DONE & Negative & Negative & Negative & Negative & Negative & Negative \\
\hline Lung & Negative & Negative & Negative & Negative & Negative & Negative & Negative \\
\hline Kidney & NOT DONE & Negative & T. gondii $*$ & Negative & Negative & Negative & Negati \\
\hline
\end{tabular}

$567 * T$. gondii, GenBank accession number AY663792; ${ }^{\circ}$ Mazzariol et al. 2012 